\title{
Optimalisasi Jumlah Produksi Menggunakan Fuzzy Inference System Metode Min-Max
}

\author{
Joko Susetyo ${ }^{1}$, Endang Widuri Asih ${ }^{2}$, Heharuman Raharjo ${ }^{3}$ \\ ${ }^{1,23)}$ Fakultas Teknologi Industri, Program Studi Teknik Industri, IST AKPRIND Yogyakarta \\ Jl. Kalisahak 28 Komplek Balapan Yogyakarta \\ Email: joko_sty@akprind.ac.id, endang.akprind@gmail.com, heharumanraharjo@gmail.com
}

\begin{abstract}
ABSTRAK
Perencanaan produksi yang tepat dapat diterapkan The GDL Konveksi guna meminimalisir over production dan stock out yang sudah terjadi sebelumnya. Fuzzy Inference System Metode Min-Max dapat digunakan dalam penentuan jumlah produksi kaos guna mencapai produksi yang optimal. Penelitian ini bertujuan untuk mendapat output produksi yang optimal untuk bulan Juli 2019 dan membandingkan produksi perusahaan dengan produksi Fuzzy Inference System yang telah dibangun sehingga dapat mengetahui presentase kesalahan rata-rata dan nilai kebenaran prediksi. Produksi yang optimal bermanfaat untuk mengefisienkan sumber daya yang dimiliki perusahaan. Berdasarkan hasil pengolahan Fuzzy Inference System Metode Min-Max dengan variabel permintaan sebesar 2016 pcs dan variabel persediaan bulan sebelumnya (Juni 2019) sebesar 60 pcs dihasilkan jumlah produksi yang optimal sebesar 1980 pcs. The GDL Konveksi dapat memproduksi sebesar 1980 pcs untuk mendapat kondisi optimal Perhitungan presentase kesalahan MAPE sebesar 6,64\% dengan nilai kebenaran mencapai 93,36\%, hal ini menunjukkan bahwa Fuzzy Inference System Metode Min-Max dapat diterapkan untuk memprediksi jumlah produksi kaos di The GDL Konveksi dengan catatan sangat baik.
\end{abstract}

Kata kunci : permintaan, persediaan, produksi, optimal, fuzzy

\begin{abstract}
Production planning can be applied to minimize the GDL Convection over production and stock out what has happened before. Fuzzy Inference System Min-Max method can be used in determining the number of T-shirt production in order to achieve optimal production. This study aimed to get optimal production output for the month of July 2019 and compares the production company with production Fuzzy Inference System that has been built so that it can determine the average percentage error and the predicted value. The optimal production beneficial to streamline its resources. Based on the results of processing Fuzzy Inference System Min-Max method with variable demand by 2016 pcs and variable supplies the previous month (June 2019) of 60 pcs generated optimal production quantities of 1980 pcs. The GDL Convection can be produced by 1980 pcs to obtain optimal conditions Calculation of percentage error MAPE of $6.64 \%$ with a truth value reached 93.36\%, this indicates that the Fuzzy Inference System Min-Max method can be applied to predict the number of T-shirt production in the GDL Convection with an excellent record.
\end{abstract}

Keyword : demand, stock, production, optimum, fuzzy

\section{PENDAHULUAN}

Perusahaan Konveksi The GDL adalah sebuah perusahaan yang bergerak dibidang jasa konveksi yang dirintis sejak tahun 2013 di daerah Banguntapan Yogyakarta, memproduksi jasa seperti kaos, polo, kemeja, seragam, jaket, almamater, topi. Seiring perkembangan perusahaan, perusahaan juga mulai memasarkan sendiri produk-produk yang dihasilkan, menyebabkan perusahaan ini berkembang sebagai produsen dan penyalur. Produk kaos menjadi produk utama (main products) dalam lini bisnis The GDL Konveksi di dunia konveksi, karena menyumbang penghasilan terbesar dan menjadi perhatian utama The GDL Konveksi dalam mengembangkan usahanya dari awal berdiri hingga saat ini.

Permasalahan mendasar yang dialami oleh The GDL Konveksi dalam kegiatan usahanya yaitu pengambilan keputusan dalam penentuan jumlah produksi yang belum optimal, dapat terlihat adanya penumpukan stok barang dikarenakan produksi yang belebihan (over production) dan kekurangan stok (out of stock), Sehingga dampak tersebut dapat menimbulkan biaya penyimpanan dan berdampak pada kualitas produk. Data persediaan kaos di The GDL konveksi menunjukan pada bulan Maret 2018, Juni 2018, Agustus 
2018, September 2018, dan Maret 2019 mengalami kekurangan stok (out of stock) dengan total 469 pcs. Selama periode Januari 2018-Juni 2019 The GDL Konveksi mengalami kelebihan produksi (over production) tertinggi sebanyak 366 pcs pada bulan Desember 2018.

Logika fuzzy dipilih karena konsep logika fuzzy mudah dimengerti, sangat fleksibel, memiliki toleransi terhadap data-data yang tidak tepat, mampu memodelkan fungsi-fungsi nonlinier yang sangat kompleks, dapat membangun dan mengaplikasikan pengalaman-pengalaman para pakar secara langsung tanpa harus melalui pelatihan, dapat bekerjasama dengan teknik-teknik kendali secara konvensional serta didasarkan pada bahasa alami, Kusumadewi [1].

Pemodelan Fuzzy Inference System (FIS) dengan metode Min-Max sudah digunakan dalam peramalan data time series khususnya dalam bidang ekonomi dan industri. Mufid [2] menggunakan metode Min-Max untuk memprediksi penentuan jumlah produksi televisi merk "X'. Penerapan metode Min-Max juga digunakan untuk mengoptimalkan jumlah produksi minyak kelapa sawit di PT. Waru Kaltim Plantation oleh Wardani [3]. Selain itu penggunaan logika fuzzy secara luas juga dapat digunakan untuk pengoptimalan bahan baku dalam rangka menghasilkan keuntungan yang maksimal dan menghasilkan waste yang minimal seperti penentuan kombinasi produk serta mengalokasikan sumber daya secara optimal [4]. Penelitian ini bertujuan mengoptimalkan jumlah produksi serta membandingkan hasil produksi perusahaan dan hasil produksi Fuzzy Inference System.

\section{METODE PENELITIAN}

Objek dalam penelitian ini adalah kaos di the GDL Konveksi. Penelitian ini diharapkan dapat menghasilkan output yang optimal dalam penentuan jumlah produksi untuk bulan Juli 2019 serta mengetahui presentase kesalahan rata-rata perbedaan antara jumlah produksi aktual perusahaan dengan jumlah produksi menggunakan Fuzzy Inference System metode Min-Max. Data yang dibutuhkan meliputi data penjualan, data persediaan dan data produksi.

\section{Forecasting}

Peramalan adalah proses untuk memperkirakan berapa kebutuhan dimasa mendatang yang meliputi kebutuhan dalam ukuran kuantitas, kualitas, waktu dan lokasi yang dibutuhkan untuk memenuhi permintaan barang atau jasa [5]. Membuat suatu peramalan akan menimbulkan suatu kesalahan. Kesalahan peramalan dapat diukur dengan beberapa kriteria kesalahan.

MAD merupakan salah satu cara yang digunakan untuk dapat mengetahui ukuran kesalahan peramalan, MAD mengukur ketepatan ramalan dengan merata-rata kesalahan dugaan (nilai absolute masingmasing kesalahan). MAD berguna ketika mengukur kesalahan ramalan dalam unit yang sama sebagai deret asli. Nilai MAD dihitung dengan menggunakan rumus:

$$
\begin{aligned}
& \mathrm{MAD}=\frac{\sum_{t=1}^{n} y(t)-y^{\prime}(t)}{n} \\
& \text { Keterangan: } \\
& \mathrm{Y}(\mathrm{t})=\text { nilai data aktual pada periode } \mathrm{t} \\
& \mathrm{Y}^{\prime}(\mathrm{t}) \quad=\text { nilai hasil peramalan pada periode } \mathrm{t} \\
& \mathrm{T}=\text { periode peramalan } \\
& \mathrm{N} \quad \text { = banyaknya data }
\end{aligned}
$$

Mean Squared Error (MSE) digunakan untuk mengukur ketepatan nilai dugaan model yang dinyatakan dalam rata-rata kuadrat dari kesalahan. Dengan menggunakan MSE, error yang ada menunjukkan seberapa besar perbedaan hasil estimasi dengan hasil yang akan diestimasi. MSE dapat dirumuskan seperti berikut:

$$
\begin{aligned}
& \text { MSE }=\sum(\mathrm{At}-\mathrm{Ft})^{2} \\
& \text { Keterangan : } \\
& \begin{array}{ll}
= & \text { Jumlah } \\
\text { At } & =\text { Data pengamatan periode } \mathrm{t} \\
F t & =\text { Ramalan periode } \mathrm{t}
\end{array}
\end{aligned}
$$

MAPE merupakan pengukuran kesalahan yang menghitung ukuran presentase penyimpangan antara data aktual dengan data peramalan. Sacara metematis dapat MAPE dapat dilihat sebagai berikut:

$$
\text { MAPE }=\frac{\frac{\sum_{i=0}^{n} \frac{\left|X_{i}-F_{i}\right|}{X i}}{X i} \times 100 \%}{n}
$$


Keterangan :

$X_{i}=$ Permintaan aktual pada periode-i

$Y_{i}=$ Peramalan produksi pada periode- $\mathrm{i}$

$n$ = Jumlah periode peramalan yang terlibat

\section{Fuzzy Inference System}

Hasil peramalan penjualan dengan metode terpilih digunakan sebagai variabel input sebagai variabel permintaan dengan pengolahan menggunakan Fuzzy Inference System metode Min-Max. Tahapan secara umum dalam metode Fuzzy Inference System metode Min-Max adalah sebagai berikut :

1. Pembentukan himpunan fuzzy, pada metode Min-Max baik variabel input maupun variabel output dibagi menjadi satu atau lebih himpunan fuzzy sesuai dengan kondisi yang ada pada data perusahaan.

2. Aplikasi fungsi implikasi, digunakan adalah Min.

Pengambilan keputusan dengan fungsi Min, yaitu dengan cara mencari nilai minimum berdasarkan aturan ke- $\mathrm{i}$ dan dapat dinyatakan dengan:

$$
\begin{aligned}
& \alpha \mathrm{i} \cap \mu \mathrm{Ci}(\mathrm{Z}) \\
& \alpha \mathrm{i}=\mu \mathrm{Ai}(\mathrm{x}) \cap \mu \mathrm{Bi}(\mathrm{x})=\min \{\mu \mathrm{Ai}(\mathrm{x}), \mu \mathrm{Bi}(\mathrm{x})\} \\
& \text { Keterangan: } \\
& \alpha \mathrm{i}=\text { nilai minimum dari himpunan fuzzy A dan B pada aturan ke-i } \\
& \mu \mathrm{Ai}(\mathrm{x})=\text { derajat keanggotaan dari himpunan fuzzy A pada aturan ke }-\mathrm{i} \\
& \mu \mathrm{Bi}(\mathrm{x})=\text { derajat keanggotaan dari himpunan fuzzy B pada aturan ke }-\mathrm{i} \\
& \mu \mathrm{Ci}=\text { derajat keanggotaan konsekuen pada himpunan fuzzy } \mathrm{C} \text { pada aturan ke }-\mathrm{i} \text {. }
\end{aligned}
$$

3. Komposisi aturan, metode yang digunakan dalam melakukan inferensi system fuzzy menggunakan metode Max, dengan cara mengambil nilai maksimum aturan, kemudian menggunakan nilai tersebut untuk memodifikasi daerah fuzzy dan mengaplikasikannya ke output dengan menggunakan operator OR (Kusumadewi, 2010)[1].

4. Penegasan (deffuzifikasi)

Tahap terakhir dari pengolahan Fuzzy Inference System Metode Min-Max adalah proses deffuzifikasi. Proses deffuzifikasi dipergunakan untuk menaksirkan nilai keangggotaan fuzzy menjadi keputusan tertentu atau bilangan real. Deffuzifikasi dilakukan dengan menggunakan metode Centroid. Pada metode ini solusi crisp diperoleh dengan cara mengambil titik pusat $\left(\mathrm{z}^{*}\right)$, daerah fuzzy menggunakan rumus berikut:

$$
\begin{aligned}
& \mathrm{Z}^{*}=\frac{\int_{Z} z \grave{\mathrm{i}}(z) d z}{\int_{z} \grave{\mathrm{i}}(z) d z} \\
& \text { Keterangan: } \\
& \text { Z* } \quad=\text { menyatakan nilai hasil deffuzifikasi/titik pusat daerah fuzzy } \\
& \text { ì }(\mathrm{z}) \quad=\text { menyatakan nilai keanggotaan } \\
& \int_{z} i(z) d z \quad=\text { menyatakan momen untuk semua daerah hasil komposisi aturan }
\end{aligned}
$$

\section{HASIL DAN PEMBAHASAN}

\section{Forcasting}

Menggunakan data penjualan periode Januari 2019-Juni 2019 untuk mendapatkan peramalan permintaan terbaik dari beberapa metode peramalan yaitu Simple Average, Moving Average, Weighted Moving Average, Single Exponential Smoothing, Double Exponential Smoothing. Penilaian kesalahan menggunakan MAD, MSE, dan MAPE dari persamaan (1), (2), dan (3) untuk dapat mengukur tingkat ketelitian peramalan dan kesalahan. Berikut didapatkan hasil peramalan seperti Tabel 1.

Tabel 1. Perbandingan hasil peramalan

\begin{tabular}{|c|c|c|c|}
\hline Metode Peramalan & Nilai MAD & Nilai MSE & Nilai MAPE \\
\hline SA & 184,2366 & 50255,97 & 9,00853 \\
\hline MA 8 & 200,2125 & 47443,43 & 10,14217 \\
\hline WMA 3 & 194,1733 & 67299,88 & 9,583502 \\
\hline SES $\alpha=0,34$ & 181,5473 & 54580,02 & 8,989408 \\
\hline DES $\alpha=0,53$ & 186,4797 & 55835,78 & 9,260544 \\
\hline
\end{tabular}


Berdasarkan Tabel 1 didapatkan peramalan terbaik menggunakan metode peramalan Single Exponential Smoothing $\alpha=0,34$ dengan nilai MAD, dan nilai MAPE terkecil daripada permalan dengan menggunakan metode lainnya.

Hasil peramalan dilanjutkan dengan verifikasi peramalan dengan MRC. Ditemukan dia titik yang berada diluar batas kendali, dapat dikatakan bahwa peramalan tidak representatif terhadap 18 data penjualan yang ada dan fungsi peramalan belum sepenuhnya mewakili data yang ada. Terdapat dua sebaran yang tidak masuk dalam verifikasi permalan dengan Moving Range Chart (MRC) dan dapat dikatakan hasil peramalan dengan menggunakan metode Single Exponential Smoothing (SES) mampu memrepresentasikan atau mewakili data yang ada sebesar $88,88 \%$ dari 18 data permintaan yang ada.

Perbaikan peramalan tidak dimungkinkan. Sehingga hasil peramalan dilanjutkan dengan memvalidasi peramalan untuk melihat apakah output peramalan dapat sesuai dengan sistem nyata yang ada.

Menggunakan uji paired sample $t$ tes dengan nilai Sig (2-tailed) sebesar 0,283 $\geq 0,05$ maka dapat dikatakan $\mathrm{H}_{0}$ diterima, sehingga disimpulkan bahwa tidak terdapat perbedaan yang signifikan antara data permintaan aktual dan permintaan peramalan mengunakan metode permalan terpilih (Single Exponential Smoothing $\alpha=0,34$ ) dengan hasil peramalan output sebesar 2016 pcs.

Tabel 2. Rekapitulasi data Permintaan, Persediaan dan Produksi

\begin{tabular}{|c|c|c|c|}
\hline Bulan & $\begin{array}{c}\text { Permintaan } \\
\text { (pcs) }\end{array}$ & $\begin{array}{c}\text { Produksi } \\
\text { (pcs) }\end{array}$ & $\begin{array}{c}\text { Persediaan } \\
\text { (pcs) }\end{array}$ \\
\hline Januari 2018 & 1760 & 1820 & 80 \\
\hline Februari 2018 & 1720 & 1675 & 35 \\
\hline Maret 2018 & 1970 & 1850 & -85 \\
\hline April 2018 & 1985 & 2050 & 65 \\
\hline Mei 2018 & 1875 & 1900 & 90 \\
\hline Juni 2018 & 1800 & 1690 & -20 \\
\hline Juli 2018 & 1785 & 2085 & 300 \\
\hline Agustus 2018 & 2350 & 2000 & -50 \\
\hline September 2018 & 2100 & 2000 & -100 \\
\hline Oktober 2018 & 2040 & 2100 & 60 \\
\hline November 2018 & 2215 & 2287 & 132 \\
\hline Desember 2018 & 1786 & 2020 & 366 \\
\hline Januari 2019 & 1820 & 1700 & 246 \\
\hline Februari 2019 & 1660 & 1720 & 306 \\
\hline Maret 2019 & 2320 & 1800 & -214 \\
\hline April 2019 & 2210 & 2250 & 40 \\
\hline Mei 2019 & 1850 & 2085 & 275 \\
\hline Juni 2019 & 2050 & 1835 & 60 \\
\hline
\end{tabular}

Analisa Statistika Deskriptif

Berdasarkan Tabel 2 maka hasil perhitungan statistika deskriptif data permintaan, persediaan, produksi menggunakan software SPSS dapat dilihat pada Tabel 3.

Tabel 3. Analisa statistika deskriptif

\begin{tabular}{|c|c|c|c|c|}
\hline Fungsi & Variabel & $\begin{array}{c}\text { Nama } \\
\text { Himpunan } \\
\text { Fuzzy }\end{array}$ & $\begin{array}{c}\text { Semesta } \\
\text { Pembicaraan }\end{array}$ & Domain \\
\hline \multirow{6}{*}{ Input } & \multirow{3}{*}{ Permintaan } & Rendah & \multirow{3}{*}{ [1660 - 2350] } & $1660-2005$ \\
\hline & & Sedang & & $1660-2350$ \\
\hline & & Tinggi & & $2005-2350$ \\
\hline & \multirow{3}{*}{ Persediaan } & Rendah & \multirow{3}{*}{ [-214 - 366] } & $-214-76$ \\
\hline & & Sedang & & $(-214)-366$ \\
\hline & & Tinggi & & $76-366$ \\
\hline \multirow{3}{*}{ Output } & \multirow{3}{*}{ Produksi } & Sedikit & \multirow{3}{*}{ [1675 - 2287] } & $1675-1981$ \\
\hline & & Cukup & & $1675-2287$ \\
\hline & & Banyak & & $1981-2287$ \\
\hline
\end{tabular}




\section{Komposisi Aturan}

Pendefisian aturan dan variabel fuzzy dilakukan berdasarkan logika dari peneliti yang telah disesuaikan dengan kondisi perusahaan yang meliputi permintaan, persediaan dan produksi dan dengan memperhatikan hubungan antar variabel yang satu dengan yang lain, diperoleh sebanyak sembilan aturan yang dapat mengakomodir probabilitas jumlah produksi berdasarkan hubungan antara variabel permintaan dan variabel persediaan yang menghasilkan jumlah produksi, sembilan aturan yang telah dibuat seperti pada Tabel 4.

Tabel 4. Komposisi Aturan

\begin{tabular}{|c|c|c|c|c|}
\hline Aturan & Permintaan & Persediaan & $\begin{array}{l}\text { Fungsi } \\
\text { Implikasi }\end{array}$ & Produksi \\
\hline$R_{1}$ & Rendah & Rendah & $\Longrightarrow$ & Sedikit \\
\hline$R_{2}$ & Sedang & Rendah & $\Longrightarrow$ & Banyak \\
\hline$R_{3}$ & Tinggi & Rendah & $\Longrightarrow$ & Banyak \\
\hline$R_{4}$ & Rendah & Sedang & $\Longrightarrow$ & Sedikit \\
\hline$R_{5}$ & Sedang & Sedang & $\Longrightarrow$ & Cukup \\
\hline$R_{6}$ & Tinggi & Sedang & $\Longrightarrow$ & Banyak \\
\hline$R_{7}$ & Rendah & Tinggi & $\Longrightarrow$ & Sedikit \\
\hline$R_{8}$ & Sedang & Tinggi & $\Longrightarrow$ & Sedikit \\
\hline$R_{9}$ & Tinggi & Tinggi & $\Longrightarrow$ & Banyak \\
\hline
\end{tabular}

Pembuatan susunan aturan fuzzy dipengaruhi oleh banyaknya variabel input dan variabel output. Dari dua variabel input dan output, susunan aturan yang digunakan dalam penelitian ini adalah IF Permintaan (...) AND Persediaan (...) THEN Produksi (...).

\section{Deffuzifikasi}

Menggunakan bantuan dari software matlab maka perhitungan deffuzifikasi dapat menghitung jumlah produksi menurut Fuzzy Inference System pada bulan Februari 2018-Juli 2019 seperti pada Gambar 1.

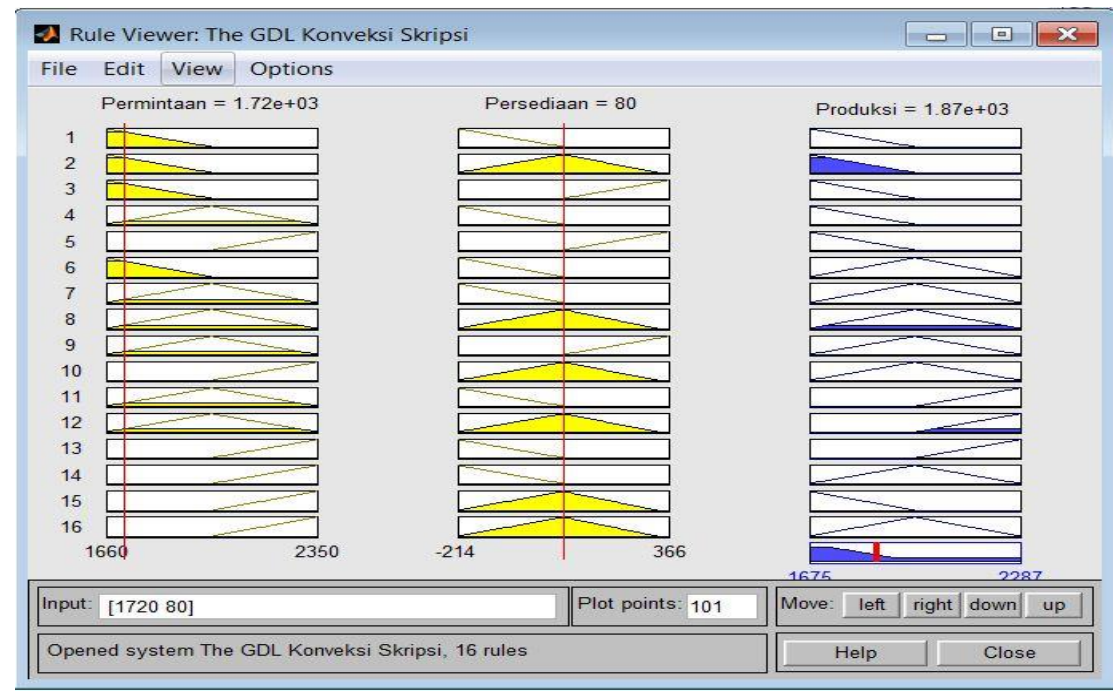

Gambar 1. Deffuzifikasi software matlab

\section{Perhitungan Mean Absolut Percentage Error (MAPE)}

Perhitungan presentase kesalahan rata-rata menggunakan persamaan (1) dalam mengukur kesalahan presentae kesalahan rata-rata perbedaan jumlah produksi Fuzzy Inference System dengan Metode MinMax didapatkan hasil seperti Tabel 5. 
Tabel 5. MAPE FIS Min-Max

\begin{tabular}{|c|c|c|c|c|}
\hline Bulan & $\begin{array}{c}\text { Permintaan } \\
(\mathbf{p c s})\end{array}$ & $\begin{array}{c}\text { Persediaan } \\
(\mathbf{p c s})\end{array}$ & $\begin{array}{c}\text { Produksi } \\
(\mathbf{p c s})\end{array}$ & $\begin{array}{c}\text { Fis Min-Max } \\
\text { (pcs) }\end{array}$ \\
\hline Januari 2018 & 1760 & 80 & 1820 & 1860 \\
\hline Februari 2018 & 1720 & 35 & 1675 & 1980 \\
\hline Maret 2018 & 1970 & -85 & 2050 & 2030 \\
\hline April 2018 & 1985 & 65 & 1900 & 1960 \\
\hline Mei 2018 & 1875 & 90 & 1690 & 1930 \\
\hline Juni 2018 & 1800 & -20 & 2085 & 1940 \\
\hline Juli 2018 & 1785 & 300 & 2000 & 2180 \\
\hline Agustus 2018 & 2350 & -50 & 2000 & 2010 \\
\hline September 2018 & 2100 & -100 & 2100 & 2040 \\
\hline Oktober 2018 & 2040 & 60 & 2287 & 2040 \\
\hline November 2018 & 2215 & 132 & 2020 & 1920 \\
\hline Desember 2018 & 1786 & 366 & 1700 & 1790 \\
\hline Januari 2019 & 1820 & 246 & 1720 & 1790 \\
\hline Februari 2019 & 1660 & 306 & 1800 & 2130 \\
\hline Maret 2019 & 2320 & -214 & 2250 & 2180 \\
\hline April 2019 & 2210 & 40 & 2085 & 1950 \\
\hline Mei 2019 & 1850 & 275 & 1835 & 1910 \\
\hline Juni 2019 & 2050 & 60 & & \\
\hline
\end{tabular}

Menggunakan persamaan (1) maka rata-rata presentase kesalahan Fuzzy Inference System Metode MinMax dibanding hasil produksi aktual perusahaan diperoleh:

$$
\begin{aligned}
\text { MAPE } & =\frac{112,839}{17} \\
& =6,637593 \\
& =6,64
\end{aligned}
$$

Produksi yang optimal pada The GDL Konveksi sudah optimal, dikatakan sudah optimal karena jumlah produksi dapat lebih kecil dari permintaan atau lebih besar dari permintaan. Jika produksi lebih kecil dari jumlah permintaan dapat membuat keuntungan perusahaan tidak maksimal tetapi dimungkinkan dengan keuntungan yang dapat diperoleh perusahaan seperti sesuai dengan sumber daya yang ada, pengefisiensian waktu, penyimpanan dan alokasi, jika produksi lebih besar dan memenuhi permintaan dapat membuat keuntungan perusahaan lebih maksimal tetapi dimungkinkan akan terjadi over production dan menimbulkan berbagai kerugian bagi perusahaan.

Pada pengoptimalan jumlah produksi di The GDL Konveksi maka perusahaan dianjurkan memproduksi kaos sesuai yang dihasilkan oleh Fuzzy Inference System Metode Min-Max yang telah dibangun dan teruji sejumlah 1980 pcs dengan permintaan sebesar 2016 agar tidak terjadinya overproduksi.

Pengaruh pada pengaplikasian Fuzzy Inference System Metode Min-Max ini memberikan dampak pada biaya produksi. dengan Jumlah produksi yang optimal memberikan dampak meminimasi biaya penyimpanan gudang karena tidak terjadi persediaan yang berlebihan atau kelebihan produksi (over production). Pengaruh lain yang terjadi jika terjadi pengoptimalan jumlah produksi adalah meminimasi biaya produksi, hal itu itu dapat dilihat dari keefektifan waktu yang dibutuhkan untuk pekerja, sehingga pekerja dapat bekerja lebih maksimal juga dapat menjaga daya tahan mesin yang digunakan. Barang yang dihasilkan dapat terdistribusi dengan cepat sehingga dapat sampai kepada konsumen tepat waktu dan meminimalkan lead time.

Pengoptimalan jumlah produksi juga mempengaruhi kebutuhan bahan baku, perusahaan dapat memperkirakan kebutuhan bahan baku pada periode selanjutnya sehingga tidak terjadi persediaan yang berlebihan. Jika perusahaan harus membeli bahan baku di lokasi yang jauh, maka biaya yang dibutuhkan juga akan lebih besar. Kelebihan biaya yang ada dapat dialokasikan untuk memperbaiki mesin yang rusak ataupun lebih dapat meningkatkan kinerja perusahaan yang juga dapat meningkatkan taraf hidup pekerjanya. 


\section{SIMPULAN}

Berdasarkan uraian di atas maka dapat disimpulkan sebagai berikut:

1. Perencanaan produksi yang optimal dapat dilakukan di The GDL Konveksi untuk meminimalisir kekurangan persediaan (out of stock) dan kelebihan produksi (over production) dengan dilakukannya penentuan jumlah produksi yang tepat.

2. Pengoptimalan jumlah produksi kaos bulan Juli 2019 menggunakan input permintaan dari metode peramalan Single Exponential Smoothing $\alpha=0,34$ sebesar 2016 pcs, dan input persediaan bulan Juni 2019 sebesar 60 pcs didapatkan hasil sebesar 2030 pcs, output produksi dikatakan optimal karena hasil produksi sudah memenuhi permintaan sebesar 2016 pcs.

3. Perbandingan output perhitungan produksi Fuzzy Inference System Metode Min-Max mendapatkan presentase kesalahan peramalan menggunakan Mean Absolut Percentage Error (MAPE) diperoleh perbandingan dengan produksi sebenarnya selama Februari 2018 hingga Juni 2019 didapat sebesar $6,64 \%$ dan dalam hal ini penentuan jumlah produksi dikatakan sangat baik karena nilai presentase kesalahan $<10 \%$.

4. Fuzzy Inference System Metode Min-Max yang telah dibangun dapat digunakan untuk memperkirakan penentuan jumlah produksi kaos di The GDL Konveksi, dengan nilai kebenaran sebesar 93,36\%.

\section{DAFTAR PUSTAKA}

[1] Kusumadewi, S,. dan Purnomo, H. (2010). Aplikasi Logika Fuzzy (Edisi Kedua).Yogyakarta : Graha Ilmu.

[2] Mufid, A. 2010. Penentuan Jumlah Produksi Televisi Merk "X" Menggunakan Metode Fuzzy Mamdani. Jurnal Teknik Unisfat 10. 2.

[3] Wardani A. R. 2017. Aplikasi Logika Fuzzy Dalam Mengoptimalkan Produksi Minyak Kelapa Sawit di PT. Waru Kaltim Plantation Menggunakan Metode Mamdani. Jurnal Informatika Mulawarman 12. 2.

[4] Asih, E. W., dan Arini, N. 2011. Perencanaan Kebutuhan Produk Guna Optimalisasi Waste dan Laba Dengan Aplikasi Fuzzy Multiobjective Optimization. Jurnal Teknologi Technoscientia 3. 2.

[5] Hajijah. S, 2010. Peramalan Hasil Produksi Minyak Kelapa Sawit Pada PT. Perkebunan Nusantara III (Persero) Sumatra Utara. Tugas Akhir. Universitas Sumatra Utara. Medan. 